\title{
A comparison of different depth ablations in the treatment of painful bullous keratopathy with phototherapeutic keratectomy
}

\author{
Raj Maini, Laurence Sullivan, Grant R Snibson, Hugh R Taylor, Michael S Loughnan
}

\begin{abstract}
Aim-To study the efficacy of phototherapeutic keratectomy (PTK) for pain relief for patients with painful bullous keratopathy and poor visual potential.

Methods-Patients with painful bullous keratopathy and poor visual potential were treated with superficial PTK (8-25 $\mu \mathrm{m})$, intermediate $(50-100 \mu \mathrm{m})$ or deep PTK (25\% stromal thickness) using the Nidek EC5000 excimer laser after manual epithelial debridement. Follow up ranged from 1 to 24 months (mean 6.5 months). Outcome measures included symptomatic relief and need for further treatment.

Results-In the superficial PTK group five of eight $(62 \%)$ patients improved symptomatically after treatment. The three (38\%) who did not improve went on to have penetrating keratoplasty for pain relief. In the intermediate depth group only two of five $(40 \%)$ patients had symptom alleviation. The three others $(60 \%)$ required further procedures. 20 of $24(83 \%)$ patients treated with deep PTK had significant or total alleviation of symptoms. Of these, one developed acute anterior uveitis 9 months after PTK and two required botulinum ptosis for persistent corneal epithelial defects, one of whom had three consecutive episodes of microbial keratitis. Three of 24 suffered occasional discomfort and one patient required a penetrating keratoplasty for continued pain.

Conclusion-PTK can be a useful therapeutic measure in painful bullous keratopathy with poor visual potential. Deep PTK appears to be more successful in pain management than superficial treatment. (Br f Ophthalmol 2001;85:912-915)
\end{abstract}

Bullous keratopathy is the painful end stage of a number of ocular conditions. Eyes with bullous keratopathy usually have an unstable epithelium and are at increased risk of developing microbial keratitis. ${ }^{1-3}$ Apart from a penetrating keratoplasty (PK), existing treatment modalities include lubricants, hyperosmotic agents, topical corticosteroid, and antibiotics, ${ }^{3}$ which typically have only a short term effect. Other options include the application of a bandage contact lens, ${ }^{3-6}$ covering the cornea with a conjunctival flap or amniotic membrane transplantation, ${ }^{7}$ diffuse anterior stromal puncture, and diamond burr polishing of Bowman's membrane. In an eye with low visual potential treatment of the pain by retrobulbar alcohol injection, enucleation, or evisceration may even be appropriate. These treatments are not totally satisfactory for a variety of reasons: application of a bandage soft contact lens and the use of steroids may predispose to bacterial keratitis, ${ }^{23}$ conjunctival flaps may be cosmetically unsatisfactory; and the risk of rejection and lifelong care required with a corneal graft can pose a formidable problem to an elderly patient.

Thomann et $a l^{8}$ have reported phototherapeutic keratectomy (PTK) to be effective in the management of patients with bullous keratopathy from a variety of aetiologies; they report that the bullae resolve and pain is abolished in a large proportion of patients treated with a superficial ablation.

The preterminal neural plexus of the cornea is located just deep to Bowman's membrane. We hypothesised that a moderately deep ablation may have a superior effect on decreasing pain by the ablation of this neural plexus. It may also decrease swelling of the corneal stroma by decreasing the quantity of mucopolysaccharide and hence osmotic load. The increased scarring associated with a deeper ablation may also result in increased stability of the epithelium.

We report our experience in treating patients with painful bullous keratopathy and poor visual potential with both superficial and deep PTK.

\section{Methods}

Non-randomised consecutively presenting patients with painful bullous keratopathy and poor visual potential were included in the study. Patients were recruited through the corneal clinic at the Royal Victorian Eye and Ear Hospital or by corneal clinic consultants in their rooms.

Treatments were performed under topical anaesthesia using the Nidek EC5000 excimer laser following manual corneal epithelial debridement. A central $6.0-7.5 \mathrm{~mm}$ zone was treated with a surrounding $1 \mathrm{~mm}$ blend zone. Ablation zone diameter was determined by surgeon preference, the presence of pannus, and overall corneal diameter; maximum treatment zone was limited to $7.5 \mathrm{~mm}$ in order not prejudice future treatment options (penetrating keratoplasty).

There were three patient groups:

(1) patients treated with superficial PTK-up to $25 \mu \mathrm{m}$ central zone ablations

(2) intermediate depth ablations varying from 50 to $100 \mu \mathrm{m}$ in depth
Accepted for publication 14 March 2001 
Table 1 Superficial phototherapeutic keratectomy treatment group

\begin{tabular}{|c|c|c|c|c|c|c|c|c|}
\hline Patient & Age (years) & Sex & $\begin{array}{l}\text { Indication (cause of } \\
B K \text { ) }\end{array}$ & $\begin{array}{l}\text { Depth of ablation } \\
(\mu \mathrm{m})\end{array}$ & $\begin{array}{l}\text { Diameter of } \\
\text { ablation }(\mathrm{mm})\end{array}$ & $\begin{array}{l}\text { Follow up } \\
\text { (months) }\end{array}$ & Outcome & $\begin{array}{l}\text { Complications /further } \\
\text { procedure }\end{array}$ \\
\hline 1 & 48 & $\mathrm{~F}$ & $\begin{array}{l}\text { Penetrating injury } \\
\text { Painful } \\
\text { pseudophakia }\end{array}$ & 25 & 9.0 & $1^{\star}$ & Persistent pain & $\begin{array}{l}\text { Recurrent bullae PK } \\
\text { at } 1 \text { month }\end{array}$ \\
\hline 2 & 81 & M & $\begin{array}{l}\text { Painful } \\
\text { pseudophakia }\end{array}$ & 25 & 9.0 & 6 & $\begin{array}{l}\text { Symptomatic } \\
\text { relief }\end{array}$ & nil \\
\hline 3 & 83 & $\mathrm{~F}$ & $\begin{array}{l}\text { Painful } \\
\text { pseudophakia }\end{array}$ & 25 & 9.0 & 11 & $\begin{array}{l}\text { Symptomatic } \\
\text { relief }\end{array}$ & nil \\
\hline 4 & 86 & $\mathrm{~F}$ & Painful aphakia & 8 & 9.0 & 13 & $\begin{array}{l}\text { Symptomatic } \\
\text { relief }\end{array}$ & nil \\
\hline 5 & 80 & M & $\begin{array}{l}\text { Painful } \\
\text { pseudophakia }\end{array}$ & 25 & 7.5 & $3^{\star}$ & Persistent pain & PK at 3 months \\
\hline 6 & 42 & M & $\begin{array}{l}\text { Painful } \\
\text { pseudophakia }\end{array}$ & 25 & 7.5 & $5^{\star}$ & Persistent pain & PK at 5 months \\
\hline 7 & 86 & $\mathrm{~F}$ & $\begin{array}{l}\text { Painful } \\
\text { pseudophakia }\end{array}$ & 25 & 9.0 & 12 & $\begin{array}{l}\text { Symptomatic } \\
\text { relief }\end{array}$ & nil \\
\hline 8 & 79 & $\mathrm{~F}$ & $\begin{array}{l}\text { Painful } \\
\text { pseudophakia }\end{array}$ & 25 & 9.0 & 11 & $\begin{array}{l}\text { Symptomatic } \\
\text { relief }\end{array}$ & nil \\
\hline
\end{tabular}

$\mathrm{BK}=$ bullous keratopathy, $\mathrm{PK}=$ penetrating keratoplasty, ${ }^{\star}$ time at initiation of further (different) treatment.

(3) deep PTK- $25 \%$ of central corneal thickness as assessed by ultrasound pachymetry before epithelial debridement.

Treatment depth varied between groups 1 and 2 as it became apparent that deeper ablations were feasible and could be more efficacious.

All patients were treated postoperatively with topical antibiotic (chloramphenicol) and corticosteroid (fluorometholone) one drop four times a day; both were stopped within 2 weeks of corneal epithelial healing. Patients were assessed for symptomatic relief during the postoperative period. In particular, the presence of persistent corneal epithelial defects (PED), recurrence of epithelial bullae, microbial keratitis, and requirement for further treatment were documented.

\section{Results}

The majority of patients had pseudophakic bullous keratopathy with no associated ocular or systemic disorder, patients with a different aetiology for their bullous keratopathy or associated systemic disorder are outlined in Tables 1-3.

SUPERFICIAL PTK

Eight consecutive patients with PBK were treated with superficial PTK (Table 1). Depth of treatment varied from 8 to $25 \mu \mathrm{m}$. Three patients $(38 \%)$ required penetrating keratoplasty for pain relief at 2,3 , and 5 months after PTK. Follow up on the other five $(62 \%)$ ranged from 6 to 13 months (mean 9.8 months); these five patients reported their eyes were either markedly improved or completely comfortable after the procedure.

INTERMEDIATE DEPTH PTK

Five consecutive patients were treated with intermediate depth PTK (Table 2). Three $(60 \%)$ required a penetrating keratoplasty or conjunctival flap for pain relief, only two (40\%) had alleviation of symptoms following laser.

DEEP PTK

Twenty four consecutive patients were treated with a deep PTK (Table 3). Mean preoperative pachymetry was $762 \mu \mathrm{m}$ (range 588-969 $\mu \mathrm{m}$ ). In three patients pachymetry was not assessable preoperatively (because of the marked degree of stromal oedema). These three patients were treated empirically with $250 \mu \mathrm{m}$ ablations. Mean ablation depth was $206 \mu \mathrm{m}$ (range 147-290 $\mu \mathrm{m}$ ). Follow up ranged from 1-18 months (mean 6.1 months).

Two patients continued to have pain from recurrent bullae: one went on to have a penetrating keratoplasty (Table 3, patient 19), the other had an amniotic membrane graft (Table 3, patient 2), both performed 3 months after PTK. Both patients are now symptom free.

A further two patients had intermittent discomfort and were retreated with PTK. One of these patients (Table 3, patient 20) had had an initial treatment zone of diameter $6.5 \mathrm{~mm}$ with a $250 \mu \mathrm{m}$ ablation, 1 month after treatment he presented with a large recurrent crescent shaped bulla outside the treatment zone from 4 to 7 o'clock. He was re-treated in

Table 2 Intermediate depth phototherapeutic keratectomy (PTK) group

\begin{tabular}{|c|c|c|c|c|c|c|c|c|c|}
\hline Patient & $\begin{array}{l}\text { Age } \\
\text { (years) }\end{array}$ & Sex & Indication & $\begin{array}{l}\text { Pachymetry } \\
\text { (pre-PTK, } \mu \mathrm{m})\end{array}$ & $\begin{array}{l}\text { Depth of } \\
\text { ablation }(\mu m)\end{array}$ & $\begin{array}{l}\text { Diameter of } \\
\text { ablation }(\mathrm{mm})\end{array}$ & $\begin{array}{l}\text { Follow up } \\
\text { (months) }\end{array}$ & $\begin{array}{l}\text { Epithelial } \\
\text { stability post } \\
\text { PTK }\end{array}$ & $\begin{array}{l}\text { Complications/further } \\
\text { treatment }\end{array}$ \\
\hline 1 & 86 & $\mathrm{~F}$ & Pseudophakia, pain & $\mathrm{N} / \mathrm{R}$ & 50 & 9.0 & $2^{\star}$ & \multirow{2}{*}{$\begin{array}{l}\text { recurrent } \\
\text { bullae } \\
\text { stable }\end{array}$} & PK at 2 months \\
\hline 2 & 86 & $\mathrm{~F}$ & $\begin{array}{l}\text { Painful } \\
\text { pseudophakia }\end{array}$ & $\mathrm{N} / \mathrm{R}$ & 80 & 8.0 & 24 & & nil \\
\hline 3 & 59 & $\mathrm{~F}$ & Failed PK, pain & $\mathrm{N} / \mathrm{R}$ & 100 & 6.5 & 1 & \multirow{3}{*}{$\begin{array}{l}\text { recurrent } \\
\text { bullae } \\
\text { recurrent } \\
\text { bullae } \\
\text { microcyst s }\end{array}$} & \multirow{3}{*}{$\begin{array}{l}\text { deep PTK at } 1 \\
\text { month } \\
\text { conjunctival } \\
\text { (Gunderson) flap } \\
\text { nil }\end{array}$} \\
\hline 4 & 83 & M & Pain, pseudophakia & 620 & 100 & 8.0 & $1^{\star}$ & & \\
\hline 5 & 75 & $\mathrm{~F}$ & $\begin{array}{l}\text { Pain, band } \\
\text { keratopathy, } \\
\text { microbial keratitis, } \\
\text { PED }\end{array}$ & 828 & 100 & 7.5 & 4 & & \\
\hline
\end{tabular}

PK = penetrating keratoplasty, PED = persistent epithelial defect, ${ }^{\star}$ time at initiation of further (different) of treatment. 
this area with a localised $150 \mu \mathrm{m}$ ablation with the previously treated area masked by a cyclodialysis spatula. One month later he had a further bulla, again outside the treatment zone between 2 and 4 o'clock. One month later the bulla had resolved and no further excimer ablation was required. The second of these patients (Table 3, patient 14) was re-treated 8 months after the first ablation and was pain free at 1 month.

Three other patients reported significant improvement in symptoms but still have occasional discomfort. The follow up on these three patients ranged from 2 to 7 months. The 17 other patients $(71 \%)$ describe their eyes as comfortable and pain free. Thus, symptoms were significantly or completely alleviated in a total of 20 of 24 patients ( $83 \%$ ).
COMPLICATIONS (DEEP PTK)

In addition there were three other patients who had complications, despite symptom alleviation, after PTK.

One patient (Table 3, patient 22) had delayed corneal epithelial healing following a deep PTK - he retained a 2.0 by $1.5 \mathrm{~mm}$ epithelial defect at 6 weeks. He was treated with botulinum toxin ptosis and his epithelium healed within a month.

Another patient (Table 3, patient 12) developed microbial keratitis 2 months after PTK. This healed rapidly, but he re-presented with a further episode of microbial keratitis 3 months later; this again resolved but recurred within a month. On resolution of his third episode of microbial keratitis he was left with a 1.5 by 3.0 $\mathrm{mm}$ persistent corneal epithelial defect and

Table 3 Deep phototherapeutic keratectomy group

\begin{tabular}{|c|c|c|c|c|c|c|c|c|c|}
\hline Patient & $\begin{array}{l}\text { Age } \\
\text { (years) }\end{array}$ & Sex & Indication & $\begin{array}{l}\text { Pachymetry } \\
(\text { pre-PTK, } \mu m)\end{array}$ & $\begin{array}{l}\text { Depth of } \\
\text { ablation }(\mu m)\end{array}$ & $\begin{array}{l}\text { Ablation } \\
\text { diameter } \\
(\mathrm{mm})\end{array}$ & $\begin{array}{l}\text { Follow up } \\
\text { (months) }\end{array}$ & $\begin{array}{l}\text { Epithelial stability } \\
\text { post PTK }\end{array}$ & $\begin{array}{l}\text { Complications } \\
\text { /further treatment }\end{array}$ \\
\hline 1 & 81 & $\mathrm{~F}$ & Painful aphakia & $\mathrm{N} / \mathrm{R}$ & 250 & 7.5 & 18 & stable epithelium & nil \\
\hline 2 & 59 & $\mathrm{~F}$ & $\begin{array}{l}\text { Failed corneal } \\
\text { graft }\end{array}$ & 969 & 290 & 7.5 & 12 & $\begin{array}{l}\text { recurrent pain, no } \\
\text { large bullae }\end{array}$ & $\begin{array}{l}\text { amniotic } \\
\text { membrane graft at } \\
3 \text { months }\end{array}$ \\
\hline 3 & 84 & M & $\begin{array}{l}\text { Painful } \\
\text { pseudophakia }\end{array}$ & 588 & 147 & 7.5 & 11 & microcysts & nil \\
\hline 4 & 84 & $\mathrm{~F}$ & $\begin{array}{l}\text { Painful } \\
\text { pseudophakia }\end{array}$ & 708 & 175 & 7.5 & 11 & microcysts & nil \\
\hline 5 & 84 & M & $\begin{array}{l}\text { Painful } \\
\text { pseudophakia }\end{array}$ & 900 & 250 & 7.5 & 9 & $\begin{array}{l}\text { few small recurrent } \\
\text { bullae }\end{array}$ & nil \\
\hline 6 & 89 & M & Painful aphakia & 892 & 160 & 9.0 & 10 & $\begin{array}{l}\text { few small recurrent } \\
\text { bullae }\end{array}$ & nil \\
\hline 7 & 49 & $M$ & $\begin{array}{l}\text { Failed corneal } \\
\text { graft pain }\end{array}$ & 831 & 195 & 7.0 & 7 & $\begin{array}{l}\text { recurrent bullae } \\
\text { Symptomatic } \\
\text { improvement }\end{array}$ & $\begin{array}{l}\text { occasional } \\
\text { discomfort }\end{array}$ \\
\hline 8 & 50 & M & $\begin{array}{l}\text { Birth (forceps) } \\
\text { trauma, pain }\end{array}$ & 800 & 200 & 7.5 & 5 & $\begin{array}{l}\text { microcysts } \\
\text { Symptomatic } \\
\text { improvement }\end{array}$ & $\begin{array}{l}\text { occasional } \\
\text { discomfort }\end{array}$ \\
\hline 9 & 59 & $\mathrm{~F}$ & $\begin{array}{l}\text { Buphthalmos } \\
\text { Painful } \\
\text { pseudophakia }\end{array}$ & 913 & 228 & 7.5 & 9 & microcysts & $\begin{array}{l}\text { acute anterior } \\
\text { uveitis at } 8 \text { months }\end{array}$ \\
\hline 10 & 72 & $\mathrm{~F}$ & $\begin{array}{l}\text { Painful } \\
\text { pseudophakia }\end{array}$ & 694 & 173 & 7.0 & 1 & microcysts & nil \\
\hline 11 & 70 & $\mathrm{~F}$ & $\begin{array}{l}\text { Painful } \\
\text { pseudophakia }\end{array}$ & 817 & 204 & 7.5 & 6 & microcysts & nil \\
\hline 12 & 84 & M & $\begin{array}{l}\text { Painful } \\
\text { pseudophakia }\end{array}$ & 675 & 160 & 7.5 & 8 & PED & $\begin{array}{l}\text { microbial keratitis } \\
\times 3 \text {, subsequent } \\
\text { PED requiring } \\
\text { Botox ptosis }\end{array}$ \\
\hline 13 & 86 & $\mathrm{~F}$ & $\begin{array}{l}\text { Painful } \\
\text { pseudophakia }\end{array}$ & 785 & 195 & 7.5 & 6 & microcysts & $\begin{array}{l}\text { nil } \\
\text { nil pissis }\end{array}$ \\
\hline 14 & 81 & M & $\begin{array}{l}\text { Painful } \\
\text { pseudophakia }\end{array}$ & 825 & 200 & 7.5 & 9 & recurrent bullae & $\begin{array}{l}\text { retreatment at } 8 \\
\text { months, now pain } \\
\text { free }\end{array}$ \\
\hline 15 & 75 & $\mathrm{~F}$ & $\begin{array}{l}\text { Painful } \\
\text { pseudophakia }\end{array}$ & 834 & 209 & 7.5 & 3 & microcysts & nil \\
\hline 16 & 80 & M & $\begin{array}{l}\text { Painful } \\
\text { pseudophakia }\end{array}$ & 964 & 240 & 7.0 & 4 & microcysts & nil \\
\hline 17 & 73 & $\mathrm{~F}$ & $\begin{array}{l}\text { Painful } \\
\text { Pseudophaki a }\end{array}$ & 764 & 191 & 7.5 & 3 & microcysts & nil \\
\hline 18 & 71 & $\mathrm{~F}$ & $\begin{array}{l}\text { Painful } \\
\text { pseudophakia }\end{array}$ & 810 & 190 & 7.5 & 3 & microcysts & nil \\
\hline 19 & 76 & $\mathrm{~F}$ & $\begin{array}{l}\text { Painful } \\
\text { pseudophakia }\end{array}$ & 620 & 155 & 7.5 & $3^{\star}$ & $\begin{array}{l}\text { recurrent bullae }+ \\
\text { pain }\end{array}$ & PK at 3 months \\
\hline 20 & 81 & M & Pseudophaki a & $\mathrm{N} / \mathrm{R}$ & 250 & 6.0 & 2 & microcysts & $\begin{array}{l}\text { required } \\
\text { retreatment at } 1 \\
\text { month }\end{array}$ \\
\hline 21 & 27 & $\mathrm{~F}$ & $\begin{array}{l}\text { Diabetic PVR } \\
\text { Painful } \\
\text { pseudophakia }\end{array}$ & $\mathrm{N} / \mathrm{R}$ & 250 & 7.5 & 2 & $\begin{array}{l}\text { microcysts } \\
\text { Symptomatic } \\
\text { improvement }\end{array}$ & $\begin{array}{l}\text { occasional } \\
\text { discomfort }\end{array}$ \\
\hline 22 & 60 & M & $\begin{array}{l}\text { Aphakia, pain, } \\
\text { microbial keratitis }\end{array}$ & 800 & 200 & 7.5 & 3 & PED & $\begin{array}{l}\text { Incomplete } \\
\text { epithelial healing. } \\
\text { Botox ptosis at } 1 \\
\text { month }\end{array}$ \\
\hline 23 & 83 & $\mathrm{~F}$ & $\begin{array}{l}\text { Painful } \\
\text { pseudophakia }\end{array}$ & 710 & 177 & 7.5 & 1 & microcysts & nil \\
\hline 24 & 81 & $\mathrm{~F}$ & $\begin{array}{l}\text { Failed corneal } \\
\text { graft, pain }\end{array}$ & 855 & 214 & 7.5 & 2 & microcysts & nil \\
\hline
\end{tabular}

$\mathrm{PK}=$ penetrating keratoplasty, PVR = proliferative vitreoretinopathy, PED = persitent epithelial defect, Botox $=$ botulinum toxin, ${ }^{\star}$ time at initiation of further $($ different) treatment. 
underwent a botulinum toxin ptosis. A month later his epithelium was healed and stable.

The third patient (Table 3, patient 9) had a previous history of buphthalmos and anterior uveitis and presented with a further episode of uveitis 8 months after PTK, her corneal epithelium was stable.

\section{Discussion}

Our experience suggests that PTK may be an effective treatment for the resolution of pain and discomfort in symptomatic painful bullous keratopathy. Deep PTK appears to be more successful and associated with a lower requirement for further treatment in comparison with superficial PTK.

Pires et al found that amniotic membrane transplantation resulted in alleviation of symptoms in $90 \%$ of patients with mean follow up period of 34 weeks; our results for deep PTK are comparable with this. Anterior stromal puncture, also commonly used for symptomatic BK, has been shown to decrease corneal sensitivity and area covered by bullae ${ }^{9}$ and increased the proportion of pain-free patients from $40 \%$ pretreatment to $70 \%$ posttreatment; however, this treatment may be associated with a risk of corneal perforation.

Two patients who developed persistent epithelial defects after PTK had had the routine post-PTK topical medication; it is unlikely that this treatment is implicated in the delayed epithelial healing in these patients. Those on topical antihypertensive therapy did not manifest delayed healing or further epithelial breakdown. The three patients with concomitant intraocular disease (buphthalmos glaucoma, insulin dependent diabetes, and idiopathic anterior uveitis) showed no delayed healing and had stable epithelium at last review, examination of the influence of other disorders on the outcome of PTK would require a larger study.

The main sensory nerve plexus in the cornea (derived from the nasociliary branch of the ophthalmic division of the trigeminal nerve) is located in the stroma in the immediately subepithelial region, with a lower density plexus deeper in the stroma. ${ }^{10}$ Peak sensitivity, neural density, and occurrence of bullae are maximal in the central cornea. ${ }^{11}{ }^{12}$

One rationale for this treatment is ablation of these nerve plexuses thereby reducing corneal sensation. Deep PTK would be expected to ablate the subepithelial plexus more completely than superficial PTK and in addition partially ablate the deeper plexus. The lack of discomfort in the two patients who had persistent epithelial defects following deep PTK supports this theory. This resultant neurotrophia theoretically increases the risk of epithelial breakdown and microbial keratitis; we saw little evidence of this with a stable epithelium present in the majority of patients post PTK. Indeed the excimer ablation may stabilise epithelial adhesion to the underlying stroma making the formation of large bullae less likely. ${ }^{13}$ Anterior stromal puncture has been shown to increase expression of extracellular proteins (type IV collagen, fibronectin and laminin) in bullous keratopathy. ${ }^{14}$ These substances are important in epithelial adhesion to the underlying stroma ${ }^{15}$; a similar process may occur following photoablation. Furthermore, the reduced thickness of the cornea could also reduce the extent of epithelial oedema by reducing the osmotic load of the stroma thereby increasing the efficacy of "dehydration" of the cornea by the remaining endothelium.

This treatment modality has several other advantages: it is a quick procedure, easy to perform, relatively cheap, and conserves donor corneal material for cases where visual rehabilitation is possible. Additionally hospital admission is not required and importantly the treatment does not prejudice other treatment options - such as penetrating keratoplastyshould they be required at a later time.

The two patients requiring retreatment (deep PTK) illustrate that the treatment zone should be large enough to prevent symptom recurrence from bullae reforming outside the ablation area. We now believe that at least an 8 $\mathrm{mm}$ central zone with a $1 \mathrm{~mm}$ blend zone and $25 \%$ stromal depth ablation may be appropriate to limit potential recurrence; these parameters are easily adjusted for with the Nidek EC 5000 laser used in this study.

Patients in our study were not randomised and were treated consecutively with increasing ablation depth; this introduced the possibility of selection bias, a standard ablation zone size would also increase comparability between patients. A prospective, randomised masked trial with a standardised treatment zone and depth is required to assess the efficacy of this treatment.

1 Musch DC, Sugar A, Meyer RF. Demographic and predisposing factors in corneal ulceration. Arch Ophthalmol 1983;101:1545-8.

2 Kent HD, Cohen EJ, Laibson PR, et al. Microbial keratitis and corneal ulceration associated with therpeutic soft contact lenses. CLAO F 1990;16:49-52.

3 Luchs JI, Cohen EJ, Rapuano CJ, et al. Ulcerative keratitis in bullous keratopathy. Ophthalmology 1997;104:816-22.

4 Hull DS, Hyndiuk RA, Chin GN, et al. Clinical experience with the therapeutic hydrophilic contact lens. Ann Ophthalmol 1975;7:555-62.

5 Ruben M. Soft contact lens treatment of bullous keratopathy. Trans Ophthalmol Soc UK 1975;95:75-8.

6 Levinson A, Weissman BA, Sachs U. Use of the Bausch \& Lomb Soflens Plano T contact lens as a bandage. Am $\mathcal{F}$ Lomb Soflens Plano T contact len

7 Pires RT, Tseng SC, Prabhasawat P, et al. Amniotic membrane transplantation for symptomatic bullous keratopathy. Arch Ophthalmol 1999;117:1291-7.

8 Thomann U, Meier-Gibbons F, Schipper I. Phototherapeutic keratectomy for bullous keratopathy. Br f Ophthalmol 1995;79:335-8.

9 Cormier G, Brunette I, Boisjoly HM, et al. Anterior stromal punctures for bullous keratopathy. Arch Ophthalmol 1996; 114:654-8.

10 Hogan MJ, Alvarado JA, Wadell JE. In: Histology of the human eye. An atlas and textbook. 1st ed. Philadelphia: Saunders, 1971:62-3.

11 Draeger J, Koudelka A, Lubahn E. On the aestheiometry of the cornea. Klin Monatsbl Augenheilkd 1976;169:407-21.

12 Rozsa AJ, Beuerman RW. Density and organisation of free nerve endings in the corneal epithelium of the rabbit. Pain 1982;14:105-20.

13 Kaufman HE. Surgical approaches to corneal wound healing. Arch Ophthalmol 1992;202 (suppl):84-7.

14 Hsu JKW, Rubinfeld RS, Barry P, et al. Anterior stromal puncture. Immunohistochemical studies in human cornea. Arch Ophthalmol 1993;111:1057-63.

15 Ohji M, Mandarino L, SunderRaj N, et al. Corneal epithelial attachment with endogenous laminin and fibronectin. Invest Ophthalmol Vis Sci 1993;34:2487-92. 